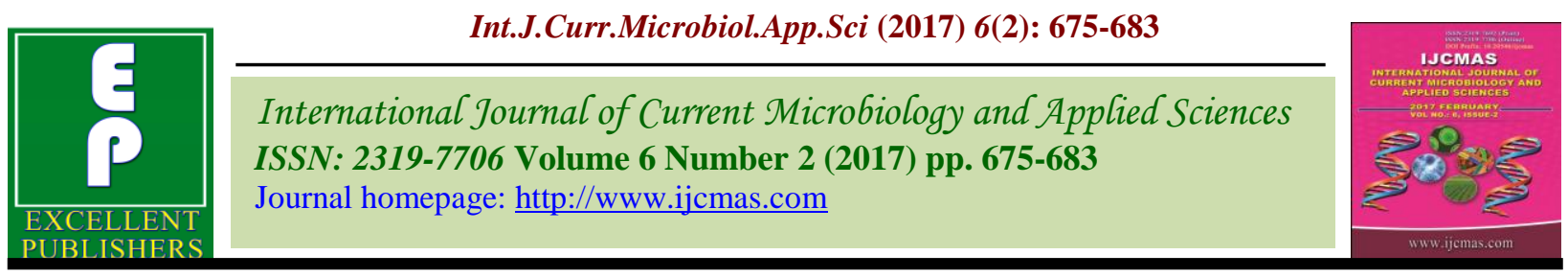

Original Research Article

http://dx.doi.org/10.20546/ijcmas.2017.602.076

\title{
Quality Analysis of Vacuum Packed Super Chilled Chicken Breast at 24 hour Storage
}

\author{
K.S. Rathod ${ }^{1 *}$, R.K. Ambadkar ${ }^{1}$, B.M. Naveena ${ }^{2}$ and S.K. Devatkal ${ }^{2}$ \\ ${ }^{1}$ Department of Livestock Products Technology, Nagpur Veterinary College, \\ Nagpur (M.S.), India \\ ${ }^{2}$ National Research Centre on Meat, Chengicherla, Hyderabad, Telangana State, India \\ *Corresponding author
}

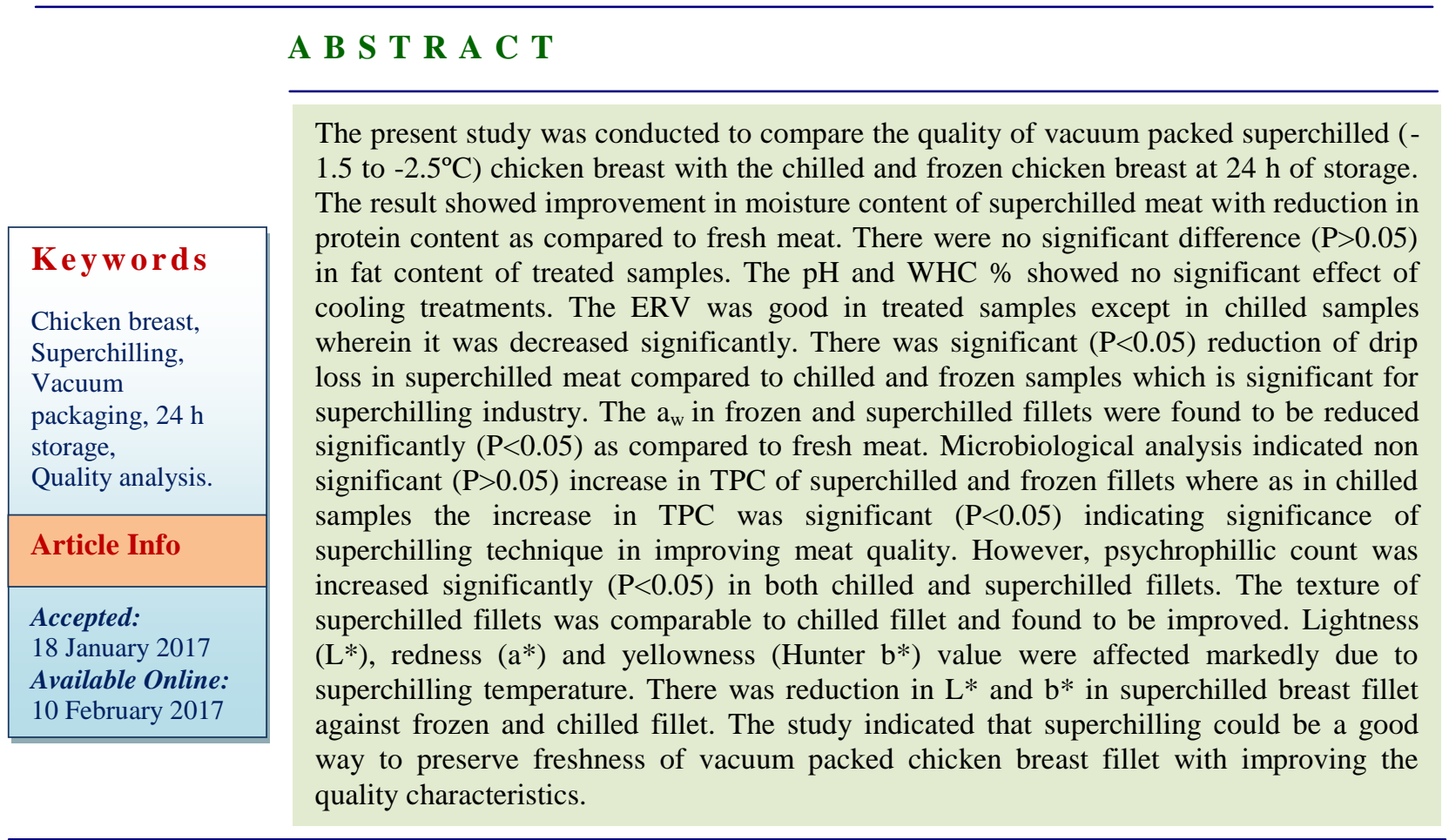

\section{Introduction}

Consumption of meat is continuously increasing worldwide. Although consumption of meat is increasing world wide the significant portion of meat and meat products are spoiled every year. The significant portion of this loss is due to microbial spoilage (Heinz and Hautzinger, 2007). Chilling is critical for meat hygiene, safety, shelf life, appearance and nutritional quality (Zhou $e t$ $a l$, 2010). Chilling also helps to prevent denaturing of proteins which may lead to bacterial attack as they are more susceptible to denaturated protein than native protein. On the other hand, cold-shortening and toughening may result from ultra-rapid chilling of pre-rigour meat (Ockerman and Basu, 2004). 
Freezing is one of the best methods for preserving food and extending its shelf life. However, food qualities such as texture, color and water holding capacity decreases after freezing and thawing. Meat contains about $50-75 \%$ by weight water, depending on the species and the process of freezing converts most of water into ice (Heinz and Hautzinger, 2007). Freezing rate (slow and fast) affects the quality of frozen meat significantly. Fast freezing produce better quality meat than slow freezing (Garthwaite, 1997).

Superchilling is a different concept than refrigeration and freezing having potential to reduce storage and transport costs (Reynolds, 2007). Super-chilling refers to the temperature zone below its initial freezing point $\left(1-2^{\circ} \mathrm{C}\right)$ but where ice crystals are not generated. In this process, instead of adding external ice to the food product, part of the internal water is frozen and works as a refrigeration reservoir, ensuring its refrigeration during distribution and transportation (Bahuaud et al., 2008). The main advantage of this method of preservation over traditional methods is that it increases the shelf life of meat for up to 4 times. Although most microbial activities are stopped or inhibited, chemical and physical changes may progress and in some cases are even accelerate (Magnussen et al., 2008).

The superchilling process was described as early as 1920 by Le Danois, and the terms "superchilling", "partial freezing" and "deep chilling" are used to describe a process by which food products are stored between their initial freezing point $\left(-0.5{ }^{\circ} \mathrm{C}\right.$ to $-2.8{ }^{\circ} \mathrm{C}$ for most food) and $1-2{ }^{\circ} \mathrm{C}$ below this temperature in most reports (Chang et al., 1998; Duun and Rustad, 2007; Magnussen et al., 2008). Compared with traditional chilling technology, superchilling can retain better food quality and prolong the shelf life of most stored food by at least $1.5-4$ times (Kaale $e t$ al., 2011). It can also reduce the use of freezing/thawing and thereby a lower energy cost was involved in superchilling in terms of transportation and retailing compared with freezing technology (Zhou, et al., 2010). Previous studies have investigated the effects of superchilling on the shelf life and quality parameters of aquatic products only at a special temperature (Gallart-Jornet et al., 2007; Kaale et al., 2014; Fernandez et al., 2009; Olafsdottir et al., 2006). The formation and growth of intra- and extracellular ice crystals during superchilling storage are significant. These crystals accelerate the extent of myofiber detachment and breakage (Bahuaud et al., 2008; Kaale et al., 2013). However there are few published studies on effect of superchilling on shelf of livestock products (Jeremiah and Gibson, 1997 in pork cuts; Jeremiah and Gibson, 2001 in beef steaks) and meat (Gill and McGinnis, 1995 in beef; Liu et al., 2012 in beef; Lan et al., 2016 in rabbit meat) and only few literature concerning chicken breast (Lawrence et al., 2010) has been published.

Since the studies describing the effect of superchilling temperature on the physicochemical and microbiological quality of chicken breasts not yet been published, the present study was conducted to focus effect of superchilling process on vacuum packed chicken breast fillet and compared with chilled and frozen breast fillet at $24 \mathrm{~h}$ of storage.

\section{Materials and Methods}

\section{Meat procurement and treatment}

The live broiler birds weighing 1.25 to $1.5 \mathrm{~kg}$ weight were procured from Indian Broiler, Nagpur and then freshly dressed poultry carcass were kept in refrigerator for $12 \mathrm{~h}$ for ageing which were deboned. Breast fillets were vacuum packed in Low density 
Polyethylene (LDPE) pouches and shifted to freezer $\left(-20^{\circ} \mathrm{C}\right)$ for cooling until the core temperature was approximately $-0.5^{\mathrm{O}} \mathrm{C}$ (about $1 \mathrm{~h}$ and $40 \mathrm{~min}$.) was reached and then two samples were immediately transferred to store at chilling $\left(0\right.$ to $\left.4^{\mathrm{O}} \mathrm{C}\right)$ and superchilling $(-1.5$ to $-2.5^{\mathrm{O}} \mathrm{C}$ ) temperature for $24 \mathrm{~h}$. The fresh meat was analyzed on the day of processing.

\section{Physico-chemical analysis}

The proximate composition (moisture, fat and protein) of all treated samples were determined by using the standard methods of AOAC (1995).

The $\mathrm{pH}$ of a product was determined by method of AOAC (1995). Ten g sample was added in $50 \mathrm{ml}$ distilled water and fine suspension was prepared. Then glass with combined electrode of digital $\mathrm{pH}$ meter was immersed in the suspension (Model: Systronics Digital pH meter 802).

The water holding capacity (WHC) of meat determined as described by Wardlaw et al., (1973) with slight modification. 20g of minced meat sample was blended with $30 \mathrm{ml}$ chilled $\mathrm{NaCl}(0.6 \mathrm{M})$ in centrifuge tube which was stirred for $1 \mathrm{~min}$ with the help of glass rod which was then hold at $40 \mathrm{C}$ for $15 \mathrm{~min}$, after that sample was allowed to centrifuge at $5000 \mathrm{rpm}$ for $15 \mathrm{~min}$ (REMI- R- 24). The supernatant obtained was measured and amount of water retained by sample was expressed in percentage.

The ERV was estimated according to the procedure described by Strange et al., (1977). Twenty five gram of minced meat was blended with $100 \mathrm{ml}$ distilled water and homogenate was filtered through a Whatman filter paper No. 1. The volume of filtrate collected in first 15 min was recorded as ERV of the respective sample.
Drip loss of meat samples were determined by the method (AOAC, 1995) from the known weights of before and after thawing and expressed as:

$$
\% \text { Drip loss }=\quad \frac{\text { Initial weight }- \text { Final weight }}{- \text { Initial weight }^{-}} \times 100
$$

Water activity was measured by Rotronic hygropalm-HP23-AW by putting $1 \mathrm{~g}$ sample in sample cup and aw was recorded after 1 min, at the specific temperature $\left(25^{\circ} \mathrm{C}\right)$.

\section{Instrumental colour}

The colour was determined using Hunter Lab Miniscan XE Plus Colorimeter (Hunter Associates Laboratory Inc., Reston, VA, USA) at National Research Centre on Meat, Hyderabad using illuminant D65 and the $10^{\circ}$ standard observer angle. Meat colour was measured at the surface of breast fillet $30 \mathrm{~min}$ after pack opening in order to allow colour stabilization on exposure to air and then $\mathrm{L}^{*}$ (Lightness), $\mathrm{a}^{*}$ (redness) and $\mathrm{b}^{*}$ (yellowness) values were measured.

\section{Texture (shear force value) analysis}

To measure shear force $(\mathrm{N})$, breast fillet were cooked and six subsamples in a cylindrical shape (diameter $8 \mathrm{~mm}$ ) were taken from each sample, longitudinally and in the direction of the muscle fibers using tissue borer. The Warner - Bratzler shear force (WBSF) of the cores were measured using texturometer (Tinius Olsen, Model H1KF, 6 Perrywood Business park, Redhill, RH1 5DZ, England) with $\mathrm{V}$ shaped stainless steel Blade $\left(60^{\circ}\right.$ angle) and triangular whole in the middle. The cores were sheared perpendicular to the muscle fibre orientation with 75 Newton load range and a cross head speed set at 200 $\mathrm{mm} /$ minute. The force required to shear the samples were recorded in Newton $(\mathrm{N})$. 


\section{Determination of microbiological quality}

The determination of total plate count, pychrophillic count and coliform count were determined following the standard method of APHA (1992).

\section{Sample preparation}

Ten $g$ of meat sample was taken near flame in a sterile mortar with the help of sterilized forceps and scissor. To it $90 \mathrm{ml}$ of sterile $0.1 \%$ peptone water was added and fine suspension was prepared using a sterile pestle for $2 \mathrm{~min}$. to get $10^{-1}$ dilution. One $\mathrm{ml}$ of this dilution was transferred to $9 \mathrm{ml}$ of sterile $0.1 \%$ Peptone water in a test tube and mixed uniformly to get $10^{-2}$ dilution. Subsequent dilutions were made as per the requirement using the same procedure.

\section{Total plate count}

Plate count agar $(23.5 \mathrm{~g})$ was suspended in one liter distilled water, boiled to dissolve the medium completely and $\mathrm{pH}$ was adjusted to $7.0+0.2$. It was sterilized by autoclaving at $15 \mathrm{lbs}$ pressure (1210C) for $15 \mathrm{~min}$. About 20 $\mathrm{ml}$ of molten media at $45^{\circ} \mathrm{C}$ was poured to each sterile Petridish in duplicate after dropping of $1 \mathrm{ml}$ inoculum of suitable dilution. The plate were kept for solidification and incubated at $37+1^{\circ} \mathrm{C}$ for $24 \mathrm{hrs}$. Plates showing 30 - 300 colonies were counted and expressed as $\log _{10} \mathrm{cfu} / \mathrm{g}$ of meat sample.

\section{Psychrophilic count}

The procedure of similar to TPC was used for determination of psychrophillic count, except that the plates were incubated at $4+1^{0} \mathrm{C}$ for 7 days. Colonies were counted and results were expressed as $\log _{10} \mathrm{cfu} / \mathrm{g}$ of sample.

\section{Coliform count}

For coliform estimation Mac Conkey agar was prepared and $1 \mathrm{ml}$ of inoculum of each dilution was placed in duplicate Petridishes. The sterile molten and cooled $\left(45^{\circ} \mathrm{C}\right)$ medium was poured and mixed thoroughly in Petridishes. After solidification of medium, the Petridishes were incubated at $37+1{ }^{\circ} \mathrm{C}$ for $24 \mathrm{hrs}$. Pink coloured colonies were counted and expressed as $\log _{10} \mathrm{cfu} / \mathrm{g}$ of meat sample.

\section{Statistical analysis}

The experiment was repeated on three separate occasions and the reading was taken in duplicate using duplicate subsamples. The data obtained was analyzed using online data analysis package WASP (Web Agri Stat Package) developed by ICAR-Central Costal Agricultural Research Institute, Goa. The significance was defined at a level of $\mathrm{P}<0.05$.

\section{Results and Discussion}

The effect of superchilling process on vacuum packed breast fillet was analyzed after temperature equalization ( $24 \mathrm{~h}$ storage) for various physicochemical and microbiological qualities has been summarized in table 1 .

\section{Proximate composition}

The mean moisture value of fresh and superchilled breast fillet was found to be $74.96+0.25$ and $75.74+0.53$ respectively which did not differ significantly $(\mathrm{P}>0.05)$. However, chilled meat showed significantly higher moisture content compared to frozon and superchilled breast fillet indicating that the superchilling may reduce the moisture content in the meat. This reduction could be due to evaporation of moisture from meat during storage (Arief et al., 1989) and sublimation of surface water of the meat to colder surface in the vicinity of freezer (Taylor et al., 1990).

The results indicated that these different cooling treatments have significant effect on protein content which was decreased $(\mathrm{P}<0.05)$ 
as compared to fresh meat which might be due to protein denaturation, as also exhibited in drip loss in this study and proteolysis induced by enzymatic activities of psychographs (Peterson and Gunderson, 1960) as well as increased microbial growth resulted from higher water activity (aw) and enzymatic autolysis (Rao et al., 1998).

The fat content of chilled $\left(4^{\circ} \mathrm{C}\right)$, frozen $\left(-18^{\circ} \mathrm{C}\right)$, superchilled $\left(-1.5\right.$ to $\left.-2.5^{\circ} \mathrm{C}\right)$ and fresh breast fillet showed no significant difference.

\section{pH, WHC and ERV}

Though the $\mathrm{pH}$ of superchilled breast fillet is reduced compared to fresh meat, all the treated samples showed no significant differences. This decreased $\mathrm{pH}$ in the treated samples, though non significant, could be due to the post mortem conversion of muscle glycogen to lactic acid which has an important bearing on keeping quality of meat (Gracy, 1981).

The water holding capacity (WHC) and thus the liquid loss (LL), of muscle is regarded as an essential quality parameter and a high WHC is of great importance both to the industry and the consumer (Dunn and Rustad, 2007). It influences the appearance of the muscle before cooking, its behavior during cooking and its juiciness when consumed (Olsson, 2003). The per cent WHC of chilled $\left(4^{\circ} \mathrm{C}\right)$, frozen $\left(-18^{\circ} \mathrm{C}\right)$ and superchilled $(-1.5$ to $-2.5^{\circ} \mathrm{C}$ ) breast fillet was $61.49+0.88$, $63.16+0.72$ and $62.82+0.45$ respectively showing no significance which is in agreement with Kaale et al., (2014) who also reported non significant difference in Liquied Loss (LL) in superchilled Atlantic salmon (Salmo salar) muscle as compared to chilled and frozen samples. However, the WHC values are much lower than the WHC of fresh breast fillet. This decrease in WHC in treated samples could be attributed to the rate of post mortem $\mathrm{pH}$ decline, high ionic strength, and protein denaturation and enhanced movement of water into extracellular space (Kondaiah $e t$ al., 1986).

The ERV $(\mathrm{ml})$ of chilled $\left(4^{\circ} \mathrm{C}\right)$, frozen $\left(-18^{\circ} \mathrm{C}\right)$, superchilled $\left(-1.5\right.$ to $\left.-2.5^{\circ} \mathrm{C}\right)$ and fresh breast fillet was $27.26+0.48,29.5+0.50$, $29.0+0.42$ and $29.46+0.37 \mathrm{ml}$ respectively indicating significant $(\mathrm{P}<0.05)$ decrease in the chilled sample where as ERV of frozen and superchilled breast fillet was as good as for fresh breast fillet. This decrease in ERV in the chilled sample might be due to bacterial growth (Miller and Price, 1971).

\section{Drip loss \%}

The per cent drip loss of chilled $\left(4^{\circ} \mathrm{C}\right)$, frozen $\left(-18^{\circ} \mathrm{C}\right)$, superchilled $\left(-1.5\right.$ to $\left.-2.5^{\circ} \mathrm{C}\right)$ breast fillet at $24 \mathrm{~h}$ storage was $1.66+0.14$, $2.23+0.29$ and $1.72+0.12$ respectively indicating significant reduction in drip loss in superchilled sample compared to chilled and frozen sample. The results are in agreement with the Kaale et al., (2014) who studied superchilling effect on WHC and drip loss of Atlantic salmon (Salmo salar) muscle. These findings are significant for the superchilling industry because they provide beneficial information on the quality of food products and this reduction in drip loss due to superchilling might be due to small amount of water in frozen from as compared to frozen samples resulting in less enzymes and salt concentration in the remaining water (Kaale and Eikevik, 2014). When water form ice, there is an increased concentration of enzymes and builds up of salt concentration in the remaining water causing protein denaturation and therefore effect the protein functionality (George, 1993; Shenouda, 1980) Moreover, high drip loss in frozen sample could be due to the mechanical damage to cell membranes caused by destruction of muscular 
tissue due to freezing resulting in low WHC (Anese et al., 2012; Srinivasan, Xiong, Blanchard and Tidwell, 1997).

\section{Water activity $\left(\mathbf{a}_{\mathrm{w}}\right)$}

The $\mathrm{a}_{\mathrm{w}}$ of chilled $\left(4^{\circ} \mathrm{C}\right)$, frozen $\left(-18^{\circ} \mathrm{C}\right)$, superchilled $\left(-1.5\right.$ to $\left.-2.5^{\circ} \mathrm{C}\right)$ and fresh breast fillet at $24 \mathrm{~h}$ storage was $0.944+0.07$, $0.906+0.06, \quad 0.928+0.05$ and $0.966+0.05$ respectively indicating significant reduction of $a_{w}$ in frozen and superchilled fillet which could be due to the fact that the freezing lowers water activity (Warris, 2010). It is also observed that there is no significant difference in the $a_{w}$ of chilled and superchilled fillet as well as frozen and superchilled fillet.

\section{Microbiological analysis}

In the present study, total plate count (TPC) increased significantly $(\mathrm{P}<0.05)$ in chilled fillet as compared to fresh meat. However, increase in TPC of frozen $\left(-18^{\circ} \mathrm{C}\right)$ and superchilled $\left(-1.5\right.$ to $\left.-2.5^{\circ} \mathrm{C}\right)$ breast fillet was found to be non significant. This could be due to the damage caused to the cells through the formation of ice crystals (Warris, 2010) preventing the growth of bacteria by reducing the availability of water as it forms ice. However, Release of drip which has provided excellent medium for microbial growth (Nirmal and Benjakul, 2010) may be the reason for increase in TPC in superchilled breast fillet as compared to fresh meat.

Table.1 Effect of superchilling treatment on physicochemical qualities of vacuum packed chicken breast fillets $(n=6)$

\begin{tabular}{|c|c|c|c|c|c|}
\hline \multirow{2}{*}{$\begin{array}{l}\text { Sr. } \\
\text { No. }\end{array}$} & \multirow[b]{2}{*}{ Parameters } & \multicolumn{3}{|c|}{ Temperatures } & \multirow[b]{2}{*}{ Fresh meat } \\
\hline & & $\begin{array}{l}\text { Chilling } \\
\left(0-4^{\mathrm{O}} \mathrm{C}\right)\end{array}$ & $\begin{array}{l}\text { Freezing } \\
\left(-20^{\circ} \mathrm{C}\right)\end{array}$ & \begin{tabular}{|c|} 
Superchilling \\
$\left(-1.5\right.$ to $\left.-2.5^{\mathrm{O}} \mathrm{C}\right)$
\end{tabular} & \\
\hline 1 & Moisture (\%) & $75.85 \pm 0.50$ & $74.38 \pm 0.26$ & $75.54 \pm 0.55$ & $\begin{array}{c}74.96 \pm \\
0.15 \\
\end{array}$ \\
\hline 2 & Protein $(\%)$ & $19.09 \pm 0.21^{\mathrm{a}}$ & $19.17 \pm 0.29^{\mathrm{a}}$ & $19.20 \pm 0.26^{\mathrm{a}}$ & $20.56 \pm 0.24^{b}$ \\
\hline 3 & Fat $(\%)$ & $4.39 \pm 0.19$ & $4.31 \pm 0.21$ & $4.49 \pm 0.12$ & $4.39 \pm 0.11$ \\
\hline 4 & $\mathrm{pH}$ & $5.99 \pm 0.07^{\mathrm{a}}$ & $6.17 \pm 0.02^{b}$ & $5.99 \pm 0.05^{\mathrm{a}}$ & $6.18 \pm 0.03^{b}$ \\
\hline 5 & WHC (\%) & $62.85 \pm 1.72$ & $65.94 \pm 1.16$ & $65.84 \pm 0.57$ & $66.07 \pm 0.45$ \\
\hline 6 & $\begin{array}{l}\text { Water activity } \\
\left(a_{w}\right)\end{array}$ & $0.92 \pm 0.04^{b}$ & $0.90 \pm 0.05^{\mathrm{c}}$ & $0.92 \pm 0.06^{\mathrm{bc}}$ & $0.97 \pm 0.05^{\mathrm{a}}$ \\
\hline 7 & Drip loss $(\%)$ & $1.63 \pm 0.05$ & $2.18 \pm 0.27$ & $1.69 \pm 0.07$ & - \\
\hline 8 & $\begin{array}{l}\text { TPC } \\
\left(\log _{10} \mathrm{cfu} / \mathrm{g}\right)\end{array}$ & $4.40 \pm 0.25$ & $3.80 \pm 0.26$ & $4.18 \pm 0.22$ & $4.02 \pm 0.29$ \\
\hline 9 & $\begin{array}{l}\text { PPC } \\
\left(\log _{10} \mathrm{cfu} / \mathrm{g}\right)\end{array}$ & $2.25 \pm 0.08^{\mathrm{a}}$ & $1.54 \pm 0.12^{\mathrm{b}}$ & $1.83 \pm 0.07^{\mathrm{c}}$ & $1.44 \pm 0.03^{b}$ \\
\hline 10 & $\begin{array}{l}\text { Coliforms } \\
\left(\log _{10} \mathrm{cfu} / \mathrm{g}\right)\end{array}$ & ND & ND & ND & ND \\
\hline
\end{tabular}

Different superscripts in a row differ significantly $(\mathrm{P}<0.05)$ 
Table.2 Effect of superchilling treatment on colour and texture of vacuum packed chicken breast fillets (Colour $n=3$ and Texture $n=5$ )

\begin{tabular}{|c|c|c|c|c|c|}
\hline \multirow{2}{*}{$\begin{array}{l}\text { Sr. } \\
\text { No. }\end{array}$} & \multirow[t]{2}{*}{ Treatment } & \multicolumn{3}{|c|}{ Colour Parameters } & \multirow{2}{*}{$\begin{array}{c}\text { Texture } \\
\text { Shear Force } \\
\text { Value }(\mathrm{N})\end{array}$} \\
\hline & & $\begin{array}{c}\text { Lightness } \\
\text { L* }^{*}\end{array}$ & $\begin{array}{c}\text { Redness } \\
\mathrm{a}^{*}\end{array}$ & $\begin{array}{l}\text { Yellowness } \\
b^{*}\end{array}$ & \\
\hline 1 & $\begin{array}{l}\text { Chilling } \\
\left(0-4^{\circ} \mathrm{C}\right)\end{array}$ & $30.82 \pm 0.30$ & $-1.03 \pm 0.52$ & $6.31 \pm 0.57$ & $8.12 \pm 0.84$ \\
\hline 2 & $\begin{array}{c}\text { Freezing } \\
\left(-20^{\circ} \mathrm{C}\right)\end{array}$ & $35.11 \pm 1.13$ & $-0.30 \pm 0.53$ & $6.49 \pm 0.88$ & $8.83 \pm 0.97$ \\
\hline 3 & $\begin{array}{c}\text { Superchilling } \\
(-1.5 \text { to }- \\
\left.2.5^{\circ} \mathrm{C}\right) \\
\end{array}$ & $32.43 \pm 0.63$ & $-1.81 \pm 0.36$ & $3.83 \pm 0.56$ & $8.83 \pm 0.75$ \\
\hline
\end{tabular}

Different superscripts in a row differ significantly $(\mathrm{P}<0.05)$

Psychrophillic count increased significantly in chilled and superchilled breast fillet when compared with fresh and frozen fillet. This increased Psychrophillic count in chilled and superchilled breast fillet could be due to increased enzymatic activity of psychrotrophs at low temperature which might have contributed to deterioration of meat quality (Kandeepan and Biswas, 2007).

\section{Warner - Bratzler shear force (WBSF)}

The table 2 indicated reduction in shear force value of superchilled meat as compared to frozen fillet, though there is no significance. Compared with the shear force measured for chilled breast fillet, lower values were observed for superchilled fillet. These results are in agreement with Lan et al., (2016) who also observed lower values of shear force for superchilled hind rabbit hind leg than chilled rabbit hind leg. This reduction in shear force value could be due to the loss of membrane strength caused by ice crystal formation (Laygonie et al., 2012).

\section{Changes in colour}

Color plays an important role in the appearance, presentation and acceptability of meat. Lightness ( $\left.\mathrm{L}^{*}\right)$, redness $\left(\mathrm{a}^{*}\right)$ and yellowness (Hunter $b^{*}$ value) were affected markedly due to superchilling temperature. The result indicated significant reduction in lightness (Hunter $\mathrm{L}^{*}$ value) and yellowness (Hunter $b^{*}$ value) score in superchilled breast fillet against frozen and chilled fillet. The redness score (Hunter $a^{*}$ value) increased significantly suggesting the beneficial effect of superchilling in improving the redness of breast fillet. These results can be corroborated with the results of Lan et al., (2016) who reported significant decrease of $\mathrm{L}^{*}$ in rabbit hind legs when stored at superchilled temperature of $-4{ }^{\circ} \mathrm{C}$ and $-2.5{ }^{\circ} \mathrm{C}$ temperature. Duun and Rustad (2008) also obtained a lower $\mathrm{L}^{*}$ in salmon filets stored at $-1.4{ }^{\circ} \mathrm{C}$ than in filets stored at $-3.6{ }^{\circ} \mathrm{C}$.

In conclusion, the study indicated that super chilling could be a good alternative to preserve freshness of vacuum packed breast fillet with improvement in the quality characteristics representing an advantage over traditional chilling and freezing. It could be a good way to preserve freshness of fresh poultry meat before processing and also could have great effect on improving the quality characteristics of poultry meat and shelf life. 


\section{Acknowledgement}

The authors are thankful to the Director, National Research Centre on Meat, Hyderabad for permitting and providing necessary facilities for part of this work

\section{References}

Arief, M.A., Reddy, K.P. and Reddy, V.R. 1989. Influence of packaging (wrapping) material and storage periods on certain chemical and oranoleptic characteristics of broiler cut up parts. Kerala J. Vet. Sci., 20: 107-114.

Bahuaud, D., T. Morkore, O. Langsrud, K. Sinnes and Veiseth, E. 2008. Effects of $1.5^{\circ} \mathrm{C}$ Super- chilling on quality of Atlantic salmon (Salmo salar) pre-rigor fillets: Cathepsin activity, muscle histology, texture and liquid Leakage. Food Chem., 111: 329-339.

Chang, K.L.B., Chang, J.J., Shiau, C.Y., and Pan, B.S. 1998. Biochemical, microbiological, and sensory changes of sea bass (Lateolabrax japonicus) under partial freezing and refrigerated storage. J. Agri. Food Chem., 46(2): 682-686

Duun, A.S., and Rustad, T. 2007. Quality changes during superchilled storage of cod (Gadus morhua) fillets. Food Chem., 105(3): 1067-1075.

Fernandez, K., Aspe, E., and Roeckel, M. 2009. Shelf-life extension onfillets of Atlantic Salmon (Salmo salar) using natural additives, superchilling and modified atmosphere packaging. Food Control, 20(11): 1036-1042.

Gallart-Jornet, L., Rustad, T., Barat, J. M., Fito, P., and Escriche, I. 2007. Effect of superchilled storage on the freshness and salting behaviour of Atlantic salmon (Salmo salar)fillets. Food Chem.,103(4): 1268-1281.

Garthwaite, G.A. 1997. Fish Processing Technology 2nd Edn., Hall G.M. (Ed). Blackie Academic and Professional, Chapman and Hall, London, UK, pp.98.
George, R.M. 1993. Freezing processes used in the food industry. Trends in Food Sci. Technol., 4: 134-138.

Gill, C. and McGinnis, J. 1995. The effects of residual oxygen concentration and temperature on the degradation of the colour of beef packaged under oxygen depleted atmospheres. Meat Sci., 387394.

Gracey, J.F. 1988. Meat Hygine. 7th Edn. The English Language. Book Society and Billiere Tindall, London.

Heinz, G., and Hautzinger P. 2007. Meat processing technology for Small to medium scale producers. Food and Agriculture Organization of the United Nations Regional Office for Asia and the Pacific.

Jeremiah, L. and Gibson, L. 1997. The influence of storage and display conditions on the retail properties and case-life of display-ready pork loin roasts. Meat Sci., 17-27.

Jeremiah, L. and Gibson, L. 2001. The influence of storage temperature and storage time on colour stability, retail properties and case-life of retail-ready beef. Food Res. Int., 815-826.

Kaale, L.D., Eikevik, T.M., Rustad, T. and Kolsaker, K. 2011. Superchilling of food: A review. J. Food Engi., 107(2): 141146.

Kaale, L.D., Eikevik, T.M., Bardal, T., Kjorsvik, E. and Nordtvedt, T.S. 2013. The effect of cooling rates on the ice crystal growth in air-packed salmon fillets during superchilling and superchilled storage. Int. J. Refrigeration, 36(1): 110119.

Kaale, L.D. and Eikevik, T.M. 2014. The development of ice crystals in food products during the superchilling process and following storage, a review. Trends in Food Sci. Technol., 39: 91-103.

Kaale, L.D., Eikevik, T.M., Rustad, T. and Nordtvedt, T.S. 2014. Changes in water holding capacity and drip loss of Atlantic salmon (Salmo salar) muscle during superchilled storage. LWT - Food Sci. 
Technol., 55(2): 528-535.

Kondaiah, N., A.S.R. Anjaneyulu, V. Kesava Rao and N. Sharma. 1986. Effect of different handling condition on quality of minced buffalo meat. Indian J. Ani. Sci., 56: 677-679

Lawrance Paul, Mark Woolfe and Chrissie Tsampazi. 2010. The effect of superchilling and rapid freezing on HADA assay for chicken and turkey. $J$. Association of Public Analysts, 38: 13-23.

Leygonie, C., Britz, T.J. and Hoffman, L.C. 2012. Impact of freezing and thawing on the quality of meat: Review. Meat Sci., 91(2): 93-98.

Liu, Q., R. Wang, B.H. Kong and Y.G. Zhang 2012. Effect of superchilling storage on quality characteristics of beef as compared with chilled and frozen preservation. Adv. Material Res., 554556: $1195-1201$

Magnussen, O.M., Haugland A., Torstveit A.K., Hemmingsen S. and Johansen T.S. 2008. Advances in superchilling of food-process characteristics and product quality. Trends Food Sci. Technol., 19: 418-424.

Miller, L.S. and J.F. Price. 1971. Extract release volume (ERV) responses with aseptic and inoculated pork. J. Food Sci., 36: 70-73.

Ockerman, H.W. and Basu, L. 2004. Carcass chilling and boning. In: Encyclopedia of meat sciences, Jensen, W.K. (Ed.), Oxford: Elsevier, Pp: 144-149.

Olafsdottir, G., Lauzon, H. L., Martinsdottir, E., Oehlenschlager, J. and Kristbergsson, K.
2006. Evaluation of shelf life of superchilled cod (Gadus morhua) fillets and the influence of temperature fluctuations during storage on microbial and chemical quality indicators. J. Food Sci., 71(2): S97-S109.

Olsson, G.B. 2003. Water holding capacity and quality: studies on Atlantic halibut (Hippoglossus hippoglossus) muscle. Tromso: Institute of Marine Biotechnology, Norwegian College of Fishery Science, University of Tromso.

Peterson, A.C. and Gunderson M.G. 1960. Some characteristics of proteolytic enzymes from Pseudomonas fluorescence. Appl. Microbiol., 8: 98-103.

Rao, D.N., Nair K.K.S. and Sakhare P.Z. 1998. Meat Microbiology and spoilage in tropical countries, Microbiology of Meat and Poultry. Davies, A. and R. Board (Eds), Blackie Academic and Professional, London.

Reynolds, G. 2007. Superchilling keeps fish fresh longer, claim scientists.

Shenouda, Y.K.S. 1980. Theories of protein denaturation during frozen storage of fish flesh. Adv. Food Res., 26: 275-311.

Taylor, A.A., Down N.F. and Shaw B.G. 1990. A composition of modified atmosphere and vacuum skin packaging for the storage of red meat. Int. J. Food Sci. Technol., 25: 98-109.

Zhou, G.H., Xu X.L. and Liu Y. 2010. Preservation technologies for fresh meatA review. Meat Sci., 86: 119-128.

\section{How to cite this article:}

Rathod, K.S., R.K. Ambadkar, B.M. Naveena and Devatkal, S.K. 2017. Quality Analysis of Vacuum Packed Superchilled Chicken Breast at $24 \mathrm{~h}$ Storage. Int.J.Curr.Microbiol.App.Sci. 6(2): 675-683. doi: http://dx.doi.org/10.20546/ijcmas.2017.602.076 